Eurasscience Journals

Eurasian Journal of Forest Science (2015) 3(2): 19-27

\title{
POSSIBLE EFFECTS ON SOIL AND WATER RESOURCES OBSERVED IN NEVŞEHİR PROVINCE IN LONG ANNUAL TEMPERATURE AND RAINFALL CHANGING
}

\author{
M. Cüneyt Bağdatl1*, KorkmazBellitürk², Anahita Jabbari ${ }^{3}$ \\ ${ }^{1 *}$ The University of Nevşehir Hacı Bektaş Veli, Faculty of Engineering and Architecture, Department of Biosystem \\ Engineering, 50300, Nevşehir, Turkey, e-mail: cuneytbagdatli@gmail.com \\ ${ }^{2}$ Namık Kemal University, Agriculture Faculty, Department of Soil Science and Plant Nutrition, 59030, Tekirdağ, Turkey \\ ${ }^{3}$ Urmia University, Agricultural Faculty, Department of Water Engineering, İran
}

\begin{abstract}
This study is performed in Nevssehir province at central Anatolian parts of Turkey. The aim of the current study was to investigate the yearly changes of rainfall and temperature climatic parameters in the long data period from 1975 up to 2014 years. The total of 40 years precipitation and temperature monthly data were first separated and classified seasonally and then were assessed by Mann-Kendall and Spearman Rho tests. The long term average of monthly rainfall data was recorded about $421 \mathrm{~mm}$ and the average temperature amount was calculated $20.9^{\circ} \mathrm{C}$ for summer months. The maximum and minimum temperature values in summer months were recorded $33.5^{\circ} \mathrm{C}$ and $7.7{ }^{\circ} \mathrm{C}$ respectively. The study was performed on long term rainfall and temperature data sets in order to investigate the transformations effects on soil and water resources, and that was obvious the rainfall data did not follow an increasing slope within different years, but a serious additive trend was observed in the average, maximum and minimum long term temperature amounts. Moreover along with the increasing temperature rate at the region, the growing surface water vaporing was recorded. The gradual reduction of rainfall amounts causes some difficulties in solution and absorption of fertilizer nutrient elements by plants and in addition leads to unsufficient amounts of soil moisture in dry farming lands.
\end{abstract}

Key words: Temperature, rainfall, soil and water resources , Nevşehir

Özet

Bu çalışma Türkiye'nin İç Anadolu Bölgesi'nde yeralan Nevşehir ilinde 1975-2014 yılları arasında gözlenen uzun yıllık yağış ve sıcaklık verilerinin yıllar bazındaki değişim seyrini ortaya koymak amacıyla gerçekleştirilmiştir. Toplamda 40 ylllık yağış ve sıcaklık verileri mevsimsel bazda kendi içlerinde gruplandırılarak Mann-Kendall ve Sperman'ın Rho testine tabi tutulmuştur. Bölgede uzun yıllık ortalama toplam yağış miktarının $421 \mathrm{~mm}$ civarında seyrettiği veortalama sıcaklık değerinin ise yaz aylarında ortalama $20.9^{\circ} \mathrm{C}$ olduğu belirlenmiștir. Bununla birlikte özellikle yaz aylarındaki ortalama minimum sıcaklık değerlerinin $7.7{ }^{\circ} \mathrm{C}$ civarında seyrettiği ve ortalama maksimum sıcaklık değerlerinin ise $33.5{ }^{\circ} \mathrm{C}$ olduğu saptanmıştır. Uzun yıllar bazında değerlendirilen sıcaklık ve yağış verilerinin toprak ve su kaynakları üzerine olan etkilerinin incelendiği bu çalışmada, yağgşların artış eğiliminde olmadığı ancak ortalama, minimum ve maksimum sıcaklık değerlerinde ciddi artış trendlerinin olduğu saptanmıştır. Özellikle bölgede sıcaklığın artması ile birlikte su kaynaklarındaki açık yüzey buharlaşma miktarlarının arttığı gözlemlenmiştir. Yağışların giderek azalması topraklara uygulanan kimyasal gübrelerin çözünmesine ve bitkiler tarafından kolayca alınmasına ortam oluşturamadığı ve özellikle kuru tarım yapılan yöre topraklarında uygun nem miktarının bulunamamasına zemin hazırladığı görülmüştür.

Anahtar Kelimeler: Sıcaklık, Yağıs, Toprak ve Su Kaynakları, Nevşehir

eurasscience.com 


\section{INTRODUCTION}

Both the global reduction of farming lands and population growth rate along with the climate change phenomenon will cause lots of problems for worldwide food supply and we will face numerous nutritional problems in the near future. By gradually reaching to the 8 billion population on the earth, the mankind is really in challenge to provide the growing population food needs. The uncontrolled transformations of climatic parameters such as temperature and rainfall affect the agricultural productions in a negative way. Some of those negative effects are as follows: the increment of soil salinity, changes in $\mathrm{pH}$ amounts, the erosion of soil by water, nitrogen leaching and etc.

The environmental conditions along with climate change are so important for the future life of mankind and they should be followed consciously and some considerations might be mentioned if is required. Sometimes precipitation and temperature might have negative effects on soil, crop, water and weather. Both the climate change related transformations, especially in rainfall and temperature, or the humankind interferences in environment, may have a side effect which should not be ignored. It should not be disregarded that increasing the oxygen amount means decreasing the $\mathrm{CO}_{2}$, which is possible by more production of plants. Along with the increasing effect of fertilizers on the crop production, the harmful effects of them on environmental condition should not be ignored at all (Karaçal 2004).The evaluation of all climatic, soil and water parameters should be done in order to improve the quality and quantity of plant production practices.

In addition of soil mechanical support for plants, it provide plant with nutrient elements and water to. There is a close relationship between soil and plant. The efficient and alive soil system is really a dynamic place which includes organic materials in different various levels, minerals, water and air. One of the most important and effective factors in shaping up the efficient soils is climatic parameters.
In order to save soil and water resources and take appropriate on time decisions, it is so vital to monitor and evaluate the climate conditions. The increment of greenhouse gasses emissions in atmosphere along with the global warming and the changes of temperature and precipitation regimes, have lots of negative effects on agricultural crop production. The increasing rate of temperature together with growing surface evaporation rate of water resources especially from the scares ones, cause the gradual elimination of such resources. The reducing trend of rainfall amounts along with temperature increment disturb the soil natural cycle and its distribution.

In the current study, the observation period of 1975-2014 years have been selected in order to investigate the changes in temperature and precipitation and its unwanted effects on soil and water resources in Nevşehir province.

\section{MATERIALS AND METHODS}

The long period temperature and rainfall data sets of Nevşehir were assessed, the study site can be seen in figure (1).

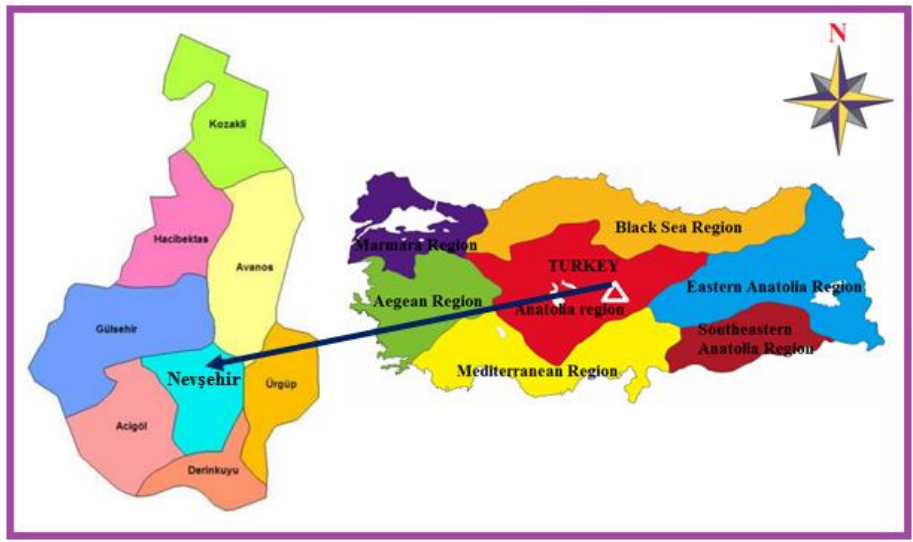

Figure 1. The location of the study area on Turkey.

The Nevşehir province with the area about $5,392 \mathrm{~km}^{2}$ is located at the central Anatolian Turkey which includes 8 residential places together with central part. The livelihood is dependent on farming, but water resources is scares and dry farming is the most dominant agricultural practice. In the current study, the whole 40 years period of 1975 up to 2014 were included and the monthly total precipitation and monthly average, minimum 
and maximum temperature data were analyzed by Mann-Kendall Spearman Rho test, Mann-Kendall correlation level test, and Sen slope trend test.
In the range of applied trend analysis tests for long period precipitation and temperature data, the

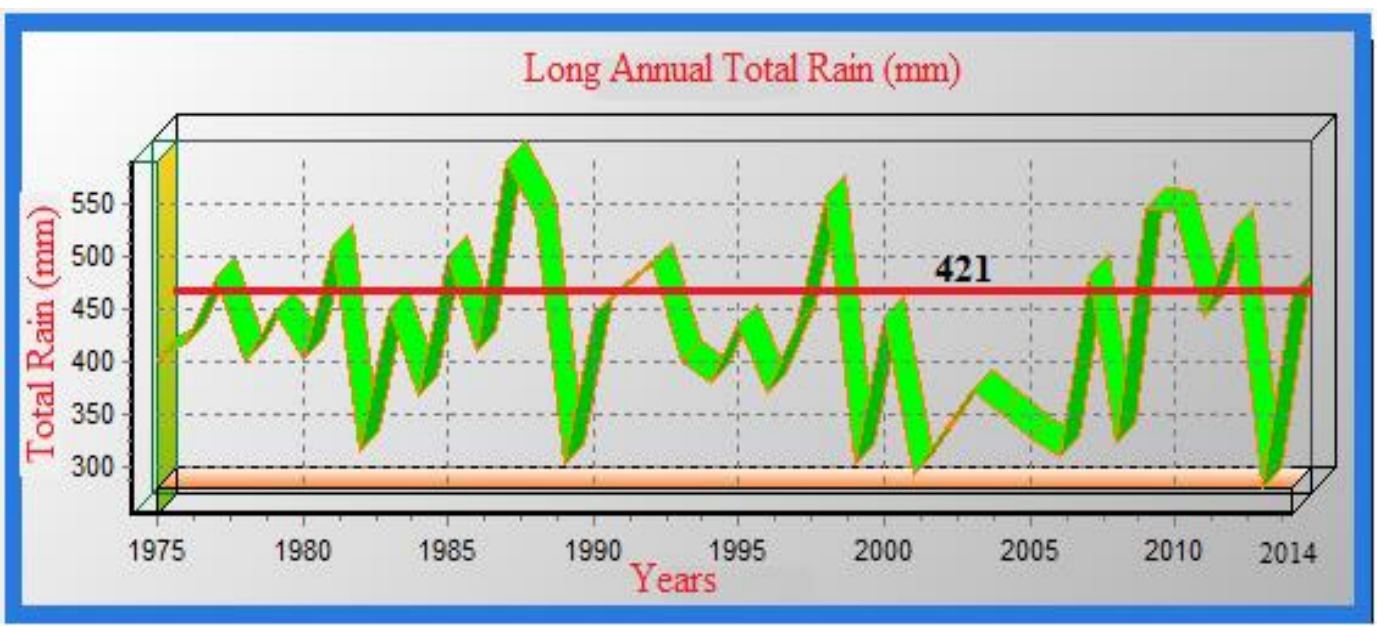

Figure 2. A Sample diagram of trend analysis.

Mann-Kendall trend test was applied first. The Mann-Kendall trend test (Mann, 1945; Kendall, 1975) is a non-parametric test which is dependent from random variable distribution type. The zero hypothesis of this test controls the existence of trend in data sets $\left(\mathrm{H}_{0}\right.$ : without trend) (Bayazit 1996). The other test was applied for precipitation and temperature data was Spearman's Rho test. The aim of mentioned test is to clarify the existence or non-existence of correlation between two observed data series, and is used to find if there is any linear trend or not (Kahya and Kalayc1 2004). The other applied statistical analyzer for data series was Sen Slope trend test. This test was first developed by Sen (1968) as a non parametric statistical test. If there exist any linear trend, for the actual slope (the changes in a time unit) the data errors or the data sets without extreme amounts may be used as a non-parametric method (Yu and et al. 1993).

The all mentioned statistical tests have been applied and the results have been illustrated as diagrams and texts. In the current study, the "trend analysis for windows" software has been utilized. (Gümüș and Yenigün 2006). The diagrams have been produced for each precipitation and temperature data separately and the existence or non-existence of a linear trend have been clarified in such a diagrams like figure (2).

\section{RESEARCH FINDINGS AND RESULTS The evaluation of long period annual precipitation}

The changes of rainfall data of the observed long term period from 1975 up to 2014 years, for Nevşehir province is illustrated in figure (3).

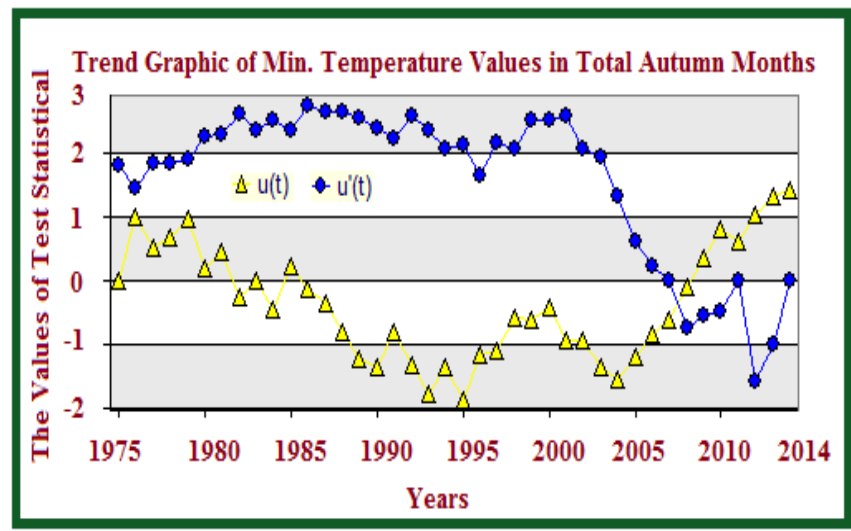

Figure 3. The change trend of annual rainfall in 1975-2014 years in Nevşehir Province.

The total monthly rainfall data from 1975 up to 2014 (40 years) has been investigated in Nevşehir. The 480 months rainfall data were chosen for the study and the rainfall changes trend was evaluated. The average precipitation amount of under studied years was about $421 \mathrm{~mm}$.

The maximum rainfall average amount was belong to 1985 about $589 \mathrm{~mm}$ and the minimum 
one is reported at 2013 which equals $281 \mathrm{~mm}$. the total monthly rainfall data in the period of 19752014 were generally lower than the average amount (421 $\mathrm{mm})$. in addition, the long term rainfall data as total monthly amounts are presented in more detail in figure (4) for the months with the maximum crop water needs: such as June, July, August and September.

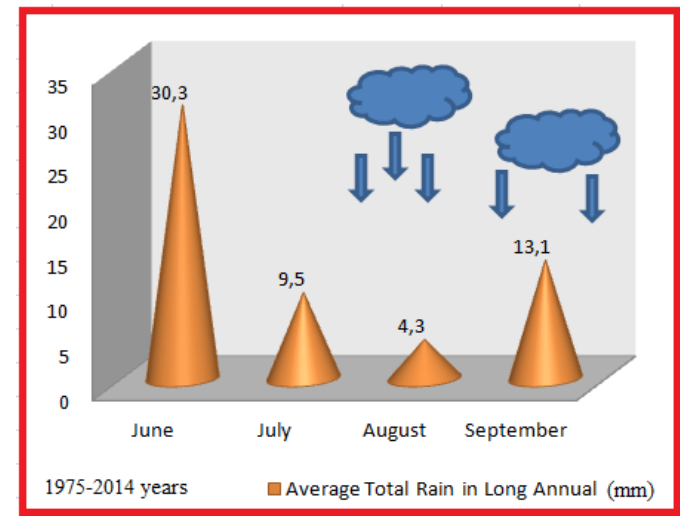

Figure 4. The months with least long term annual rainfall events.

June, July, August and September months are the most critical months in farm production because the plant water needs are at their maximum level. However especially due to global climate change, the gradually decreasing slope was observed in precipitation data series and at the same time the serious reduction in agricultural crop products has been detected.

During June months of some years in Nevşehir the average precipitation was about $30.3 \mathrm{~mm}$, while this amount reaches to $9.5 \mathrm{~mm}$ in July, 4.3 $\mathrm{mm}$ in August and again increases up to $13.1 \mathrm{~mm}$ in September along with the temperature reduction. Because of rainfall transformations due to seasonal changes, it is not suggested to compare the events of spring and summers with each other, because it may leads to unreal results.

In this respect, in order to get more realistic and beneficial results, the spring, summer, fall and winter seasons months were separated in order to not to mix the trend analysis with seasonal natural changes.

The results of the analysis done on the grouped month on the base of seasons are presented in figure (5).

eurasscience.com
By assessing the changing trend of total rainfall data of all seasons in the 1975 - 2014 period, it can be seen that the average of total rainfall of winter months is about $133 \mathrm{~mm}$. on the base of average rainfall of winters, the most rainy year was 1991 with $201.7 \mathrm{~mm}$ recorded data, and the driest winter was experienced at 1989 with $65.3 \mathrm{~mm}$ rainfall event. The average total rainfall data of spring months were generally reported close to $156 \mathrm{~mm}$, but again the rainiest spring was recorded at 1998 with $255.7 \mathrm{~mm}$ total rainfall amount.

The total average rainfall amount of summer months, due to the increasing temperature rate shows about $44 \mathrm{~mm}$ reduction in compare with spring and winter months. The highest averages of summer have been seen in 1979 and 2014 with $90.2 \mathrm{~mm}$ rainfall amount. Moreover, the averages of total rainfall events occurred during fall months was about $88 \mathrm{~mm}$ and the most wet fall season was experienced at 2014 with $190.8 \mathrm{~mm}$ total rainfall event.

\section{The evaluation of long term annual temperature}

The long period average temperature data on the base of seasonal separation was evaluated and the resulted diagrams are illustrated in figure (6).

In order to investigate the seasonal variability of temperature it is not preferred to consider whole months altogether, because it doesn't produce realistic valuable results. In this respect, the months were separated seasonally and the analysis were performed inter seasonal periodical, and as a result the average monthly temperature for winters was recorded $0.8^{\circ} \mathrm{C}$.

The minimum average temperature of winter months was reported at 1992 about $-4.72{ }^{\circ} \mathrm{C}$ and the maximum average amount belongs to 2010 equals to $6.2^{\circ} \mathrm{C}$ The maximum average amount of temperature in spring months was observed at 2014 about $14.73 \mathrm{C}^{\circ}$ and the minimum average amount was recorded at 1987 , as $7.1^{\circ} \mathrm{C}$.

When looking at average temperature amounts at summer months, the average value is about $20.9^{\circ} \mathrm{C}$ and the maximum average value is for 2010 about $25.77{ }^{\circ} \mathrm{C}$ and the minimum one occurs at 1984 which was about $18.13{ }^{\circ} \mathrm{C}$. The average 
temperature value in fall months was recorded about $11.7{ }^{\circ} \mathrm{C}$ and the maximum and minimum average amounts are about $16.97{ }^{\circ} \mathrm{C}$ and $9.50{ }^{\circ} \mathrm{C}$ were recorded respectively at 2010 and 1988 years.

Although generally the average temperature of a day is considered, but the minimum temperature occurred during a day should be mentioned to. In this respect the observed temperature amounts at the central part of the province for the period of 1975 up to 2014 on the base of seasonal changes were illustrated at the diagrams of figure (7).

While assessing the long term minimum temperature values, in winter months, the minimum temperature amount of all years is $12.4{ }^{\circ} \mathrm{C}$, and the lowest amount in minimum temperature amount was recorded at 1992 about 17.6 ${ }^{\circ} \mathrm{C}$ while the highest value of minimum averages was seen at 1981 which was about $-6.6{ }^{\circ} \mathrm{C}$.

The long period minimum temperature amounts of spring months was calculated about $-2.8{ }^{\circ} \mathrm{C}$, the lowest amount of minimum averages was recorded at 1997 about $-7.1^{\circ} \mathrm{C}$ and the highest amount belongs to 2001 which is about $1.2^{\circ} \mathrm{C}$.

The summer months minimum average of temperature was $7.7^{\circ} \mathrm{C}$ and the lowest of this data set was observed at 1984 about $3.5{ }^{\circ} \mathrm{C}$ while the highest minimum temperature data in a long term period was about $11.6^{\circ} \mathrm{C}$ in 2010 .

The average of minimum temperatures in fall months was about $-1.1 \mathrm{C}^{\circ}$ and the lowest amount in long term period minimum temperature data set was observed at 1995 and 2001 which was about $4.6{ }^{\circ} \mathrm{C}$. The value in the same data set was seen in 2012 and was about $4.3^{\circ} \mathrm{C}$.

In addition to find minimum temperature average amounts it is also important to clarify the maximum temperatures to, especially because of the negative effects of warmer temperatures on soil and water resources. In this respect, the total of 40 years data from 1975 up to 2014 were assessed in order to calculate the maximum temperature averages in each season, and the results are illustrated in figure (8). While looking at long term annual temperature data, the average maximum temperature of fall months in the 1975 - 2014 period was calculated about $25.5{ }^{\circ} \mathrm{C}$ and the highest reported value in the maximum temperature data sets belongs to 2003, about 29.1 $\mathrm{C}^{\circ}$ and the lowest ones were reported from 1986 and 1988 which was about $23.2^{\circ} \mathrm{C}$.
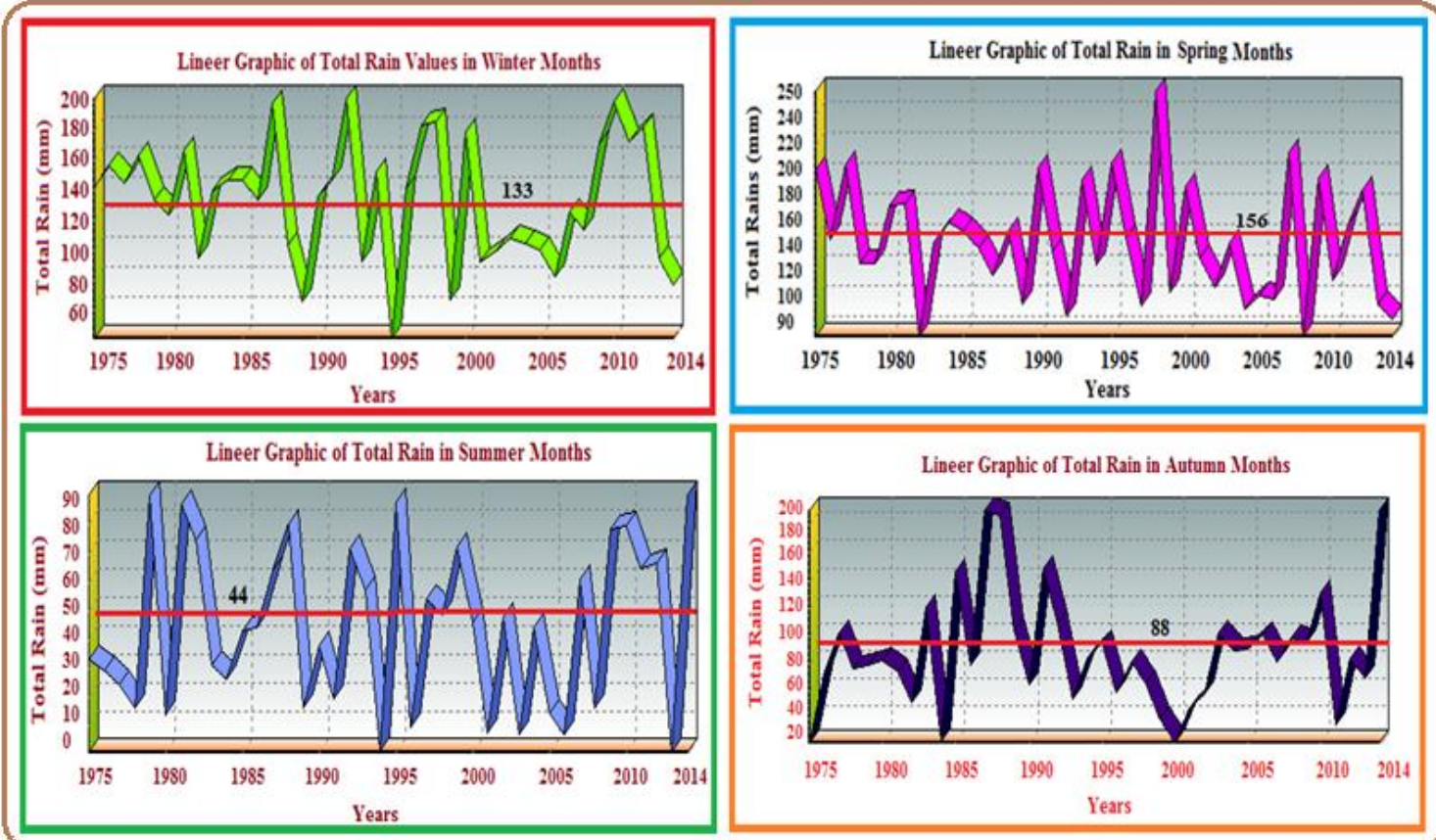

Figure 5. The changing trend of annual rains (for each season in a year from 1975 up to 2014). 


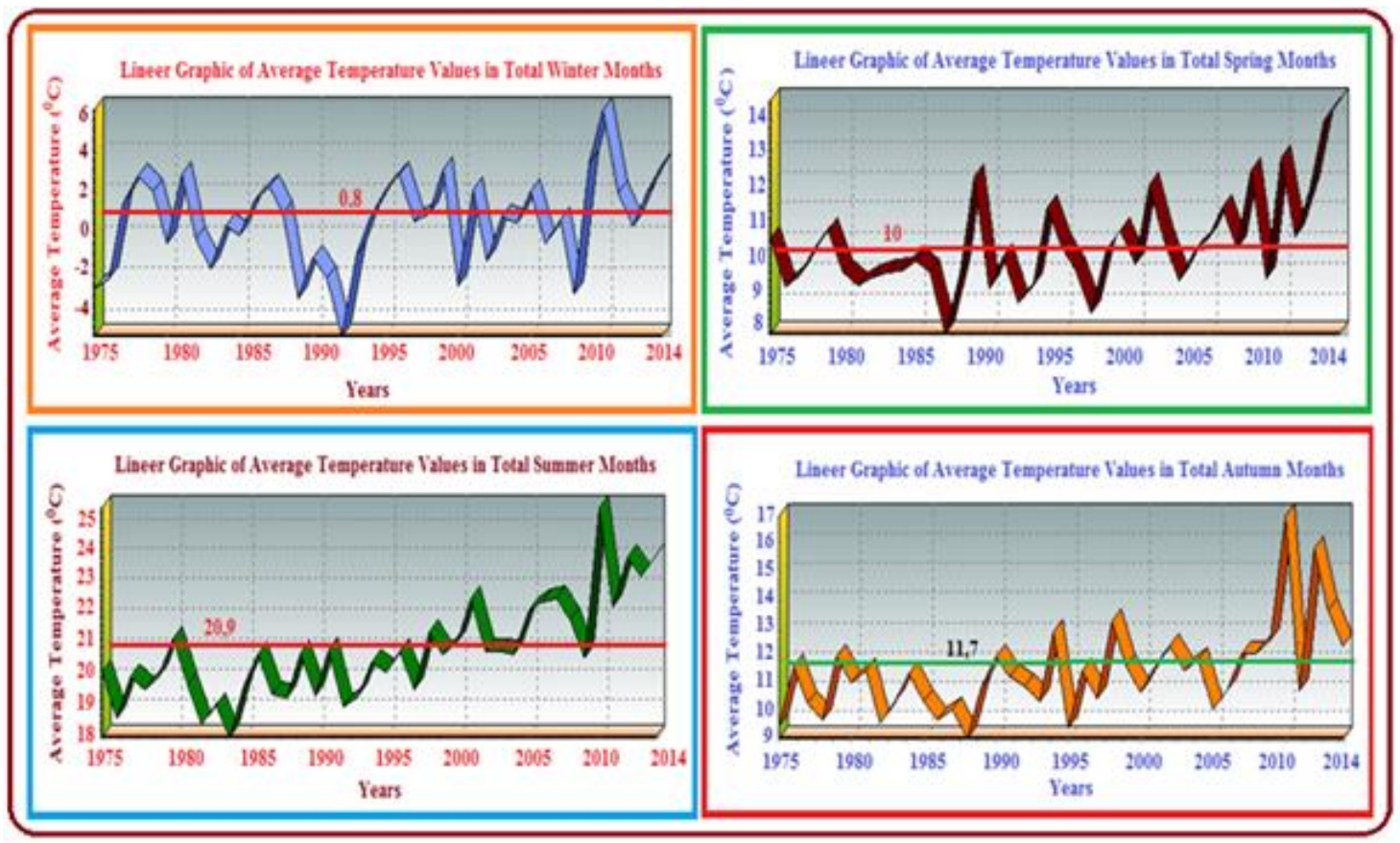

Figure 6. The changing trend of annual temperature (for each season in a year from 1975 up to 2014).
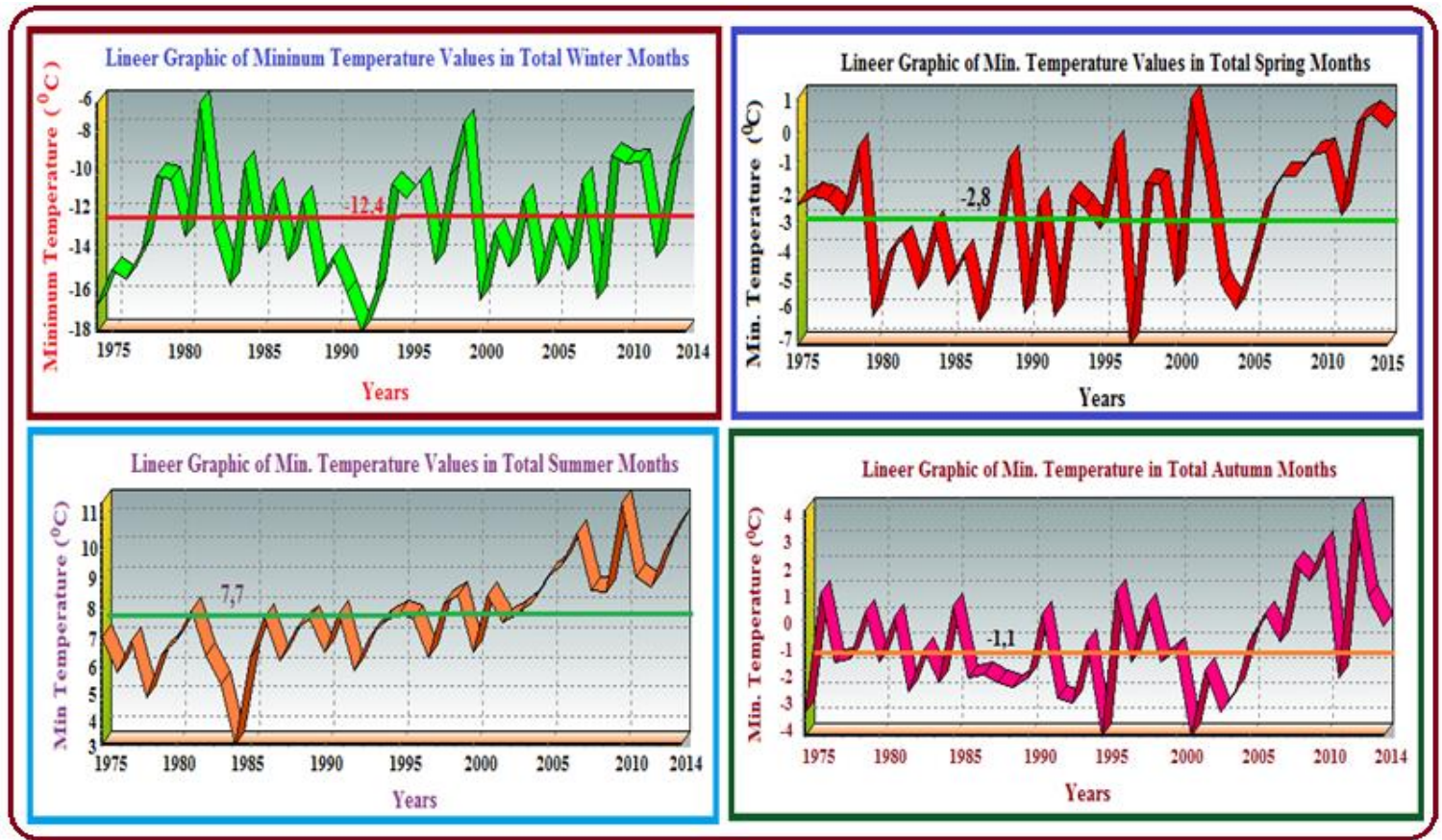

Figure 7. The changing trend of long period annual minimum temperature amounts (all season's months from 1974 - 2014).

The average of maximum temperatures in spring months was $24.1{ }^{\circ} \mathrm{C}$ and the highest value in the mentioned data set was recorded $29.6{ }^{\circ} \mathrm{C}$ for 2008 while the lowest of maximum average temperature was experienced in 1987 and 2013 which was about $21.8^{\circ} \mathrm{C}$.

The average of maximum temperatures of summer season is $33.5^{\circ} \mathrm{C}$ and the highest amount of the data set was recorded at 2007 which equals 
to $36.2{ }^{\circ} \mathrm{C}$ and the lowest average of maximum temperatures data sets was seen at 1988 about 30.8 $\mathrm{C}^{\circ}$. In a similar manner the average of maximum temperature amounts in winter months of all years is $13{ }^{\circ} \mathrm{C}$ while the maximum value of the mentioned data set was experienced at 2010 which was about $19.2^{\circ} \mathrm{C}$ and the minimum value was observed $7.8^{\circ} \mathrm{C}$ at 1992 year.

The statistical tests were performed for all long term data for observed precipitation and temperature data sets in the period of $1975-2014$ years. Table (1) summarizes the trend analysis results of rainfall and temperature changes in time.

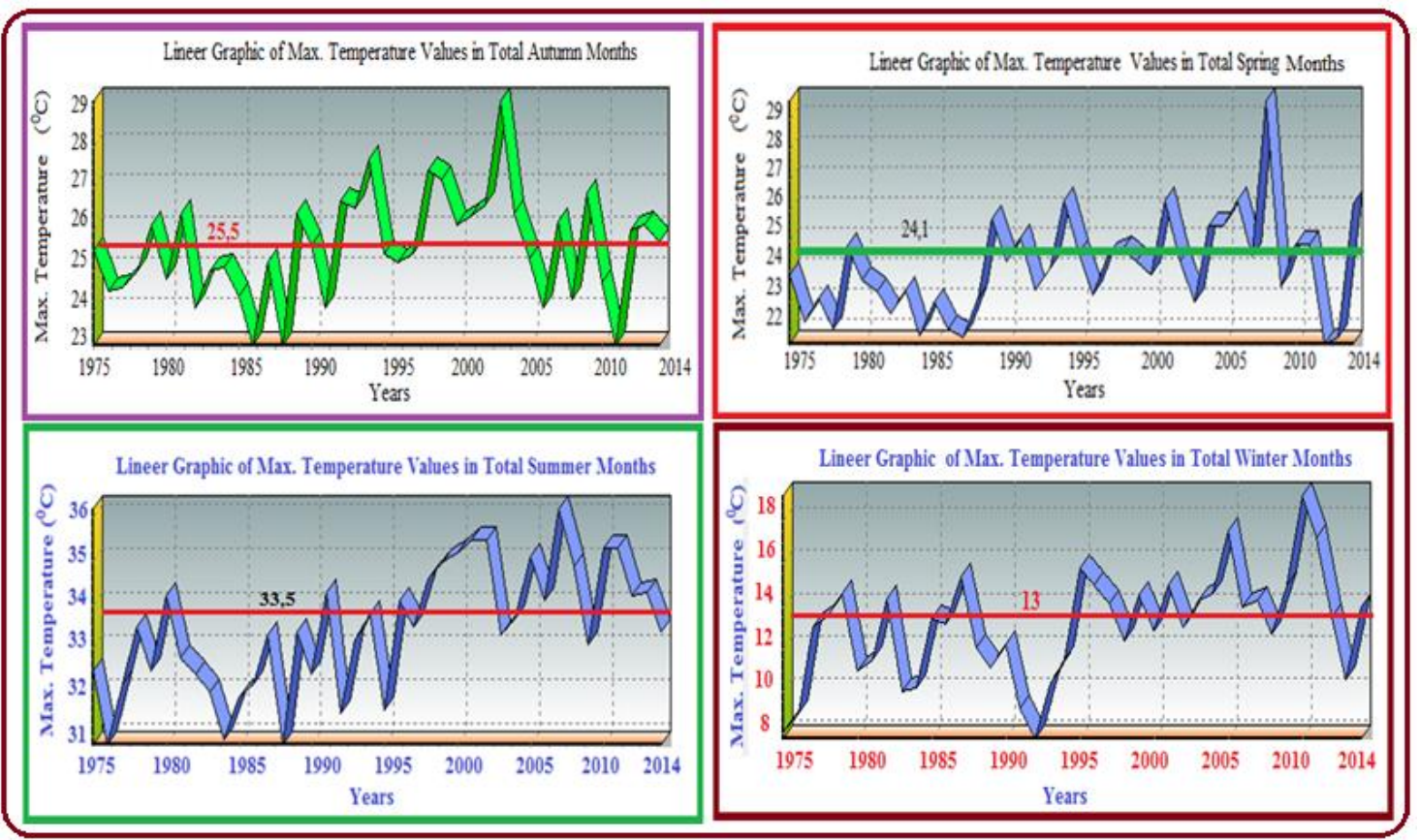

Figure 8 . The changing trend of long period annual maximum temperature amounts (all season's months from 1974 - 2014)

Table 1. The test report of Mann-Kendall and Seperman Rho statistics

\begin{tabular}{|c|c|c|c|}
\hline Climate Parameters & Periods & Mann-Kendall & Separman Rho \\
\hline \multirow{4}{*}{ Min. Temperature } & Spring & $+\hat{\imath}$ & $+\uparrow$ \\
\hline & Summer & $+\bar{t}$ & $+\overline{\hat{\imath}}$ \\
\hline & Autumn & - & - \\
\hline & Winter & - & - \\
\hline \multirow{4}{*}{ Max. Temperature } & Spring & $+\hat{\pi}$ & $+\Uparrow$ \\
\hline & Summer & + & \\
\hline & Autumn & - & - \\
\hline & Winter & $+\hat{\imath}$ & $+\hat{0}$ \\
\hline \multirow{4}{*}{$\begin{array}{c}\text { Average } \\
\text { Temperature }\end{array}$} & Spring & $+\hat{\imath}$ & $+\hat{0}$ \\
\hline & Summer & + & + \\
\hline & Autumn & + & $+\widehat{A}$ \\
\hline & Winter & - & - \\
\hline \multirow{4}{*}{ Total Rain } & Spring & - & - \\
\hline & Summer & - & - \\
\hline & Autumn & - & - \\
\hline & Winter & - & - \\
\hline
\end{tabular}

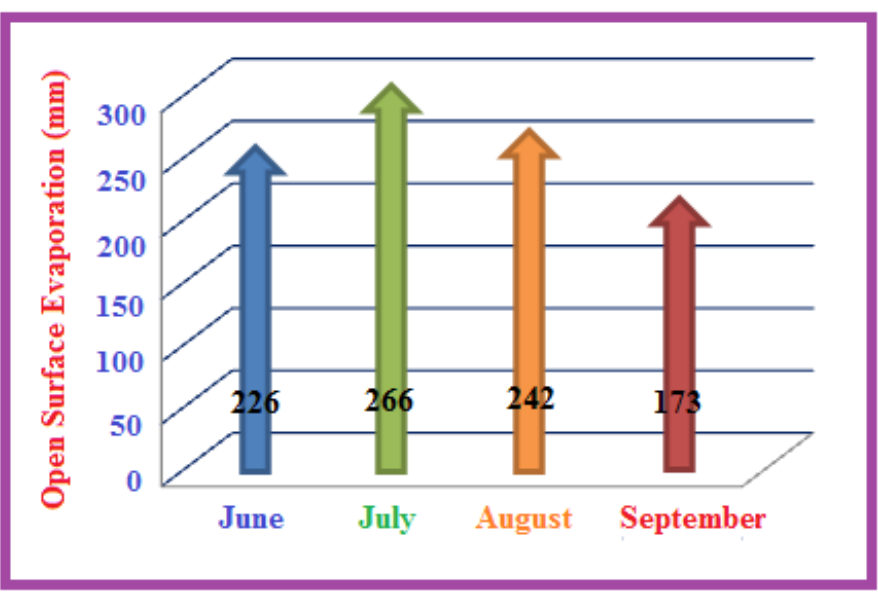

Figure 9. The average evaporation from open water surface. 
The long term average, maximum and minimum temperatures show the increasing slope with time in both Mann-Kendall and Spearman Rho tests. In this respect, the minimum temperature amounts of spring and summer season's months illustrate the growth due to these tests. The summer, spring and winters maximum temperature values again show an incremental trend with time. Moreover the serious incremental regime can be seen in the average temperature of spring, summer and fall seasons. But this huge increasing rate of temperature amount in Nevşehir, is not simultaneous with any rainfall increment.

\section{The effects of rainfall and temperature transformations on soil and water resources The effects on water resources}

Although the rainfall events of Nevşehir is pretty insufficient, but the average yearly rainfall amount is about $421 \mathrm{~mm}$ which is much more than $262 \mathrm{~mm}$ which is the average value of Turkey rainfall events. But along with the global warming, the increasing rate of temperature leads to increment of surface water evaporation. There are 3 dams located in Nevşehir which were constructed because of agricultural practices of the region: Damsa dam, Tatlarin dam and Ayhanlar dam. However, the region also Kumtepe for irrigation purposes, Yalıntaş, Kozakli - Taşlihöyük and Avanos-Özkonak pond water areas are operating for irrigation.

The temperature increasing rate causes the increment of water evaporation from the surfaces, as a result global warming may leads to run out the water resources. Especially in the months with maximum temperature and crop water requirement, such as June, July and august, the open surface water evaporation reaches to the high amounts. Figure (9) summarizes the amount of water evaporation from open surfaces at those mentioned months.

The evaporation form open water surfaces in 3 months with maximum crop water requirements, June, July and August, are respectively $226 \mathrm{~mm}$, $266 \mathrm{~mm}$ and $242 \mathrm{~mm}$. consider the July month evaporated water amount, $266 \mathrm{~mm}$, which equals to 266 liters per day from a 1 square meter, which is a considerable and significant amount in an area such as Nevşehir with insufficient water resources. The temperature and evaporation are changing in a positive slope trend but at the same time rainfall amounts are stable, which doesn't permit to compensate this distance, consequently the water resources especially reservoirs and ponds with open surfaces affected more from global warming and the water level will decreases more rapidly.

\section{The effects on soil resources}

The temperature and rainfall are 2 of the most important soil forming factors. The climate has important effect on some of the soil characters, as a result all of them should be concerned in fertilization programs. If we want mention a nice example, in Rize province, which is located at black sea region in Turkey, the high rainfall amounts arising from the climate condition of the region, decreases the $\mathrm{pH}$ amount of soils, increases the acidity of it, while in Tekirdağ province in Trace region, the unconscious fertilizer using especially Ammonium sulfate included fertilizers, and in long periods of time make the soil more acidic (Bellitürk et al. 2015).

In the tea farms of Rize region, the utilization of ammonium sulfate fertilizers causes soil salinity, even the PH amount reaches under 4, while this reality was forecasted years ago (Sağlam 2005).

As a result, a more conscious fertilizer selection along with the other reformative practices are going on in order to remediate soils. Actually it is accepted that even a wrong fertilizer selection may have unwanted effects on soil characteristics. Nowadays we may face the same conditions because of intensive or irregular rainfall events. In this respect, the needed actions should be considered and the harmful effects on soil will be decreased. This examples show that the long term data even yearly climatic data should be considered and studied in detail to plan the agricultural activities.

One of the other side effects of irregular and intensive rainfall events is soil erosion by water in farms. In order to solve the mentioned problem, along with following the climatic data in detail 
planting the cover crops in such areas is an increasing approach especially in recent years.

At the same time the organic fertilizers (such as manures, Vermicompost, thermophic compost, etc) cause approximately $75 \%$ decrement of wind erosion side effects on soils, as a result such fertilizers prevents the soil loss (Sağlam 2005).

The soil and climatic factors are so important for fruit trees productions and their acceptable functionality (Gerçekçioğlu et al. 2008). The formation of chlorophyll, flavors, colors and some other special characteristics of fruit trees need sun light. Because of this reality the sun shine hours is an effective factor on fruits development. In addition to consider the climatic conditions, it is vital to mention and analyze the weather and soil temperature, soil moisture and sunshine hours, in regions with fruit trees farm lands (Bellitürk and Sözübek 2014).

\section{CONCLUSIONS AND RECOMMENDATIONS}

In order to form the sustainable farms and the correct planning of the future, first of all the soil should be identified well and then the farmingpractices should be scheduled on the base of climate data of the specified region (Bellitürk 2011). Nowadays along with the importance of increasing the soils fertility, the sustainability protection is a vital concept to. The importance and reality of this condition is bolder by naming the 2015 as "global soil year". Because it is said that the residual efficient soils for farming will be last just about 60 years (Anonymous 2015). Consequently, it can be said that when planning for the farming activities and performing them, the climate, and water and soil resources should not be ignored. We should save efficient farm soils beside the sufficient water resources for future generations.

\section{References}

Anonymous, 2015. The International Year of Soils. Soil Science Society of America. https://www.soils.org/iys (19 October, 2015).
Bayazıt, M. (1996). İnşaat Mühendisliğinde Olasıllk Yöntemleri. İTÜ İnşaat Fakültesi Matbaası, s.245, İstanbul. (in turkish)

Bellitürk, K.(2011). Determination of Nutrient Status of Agricultural Soils in Uzunkopru County of Edirne Province. Journal of Tekirdag Agricultural Faculty, 8 (3): 8-15.

Bellitürk, K., Sozubek, B.(2014). Investigation of Conformity of the Soils Used for Field Crop Cultivation to FruitGrowing: The Case of Yeşilsırt Village. Düzce University, Journal of Science and Technology, 2 (1): 88-99.

Belliturk, K., Bağdatlı, M.C., Fidanc1, S.(2015). Importance of to be Identified of the Soils Physical and Chemical Properties at the Agricultural Production: Sample of Tekirdag Province/Malkara City. Turkish Chemical Society, Chemistry and Industry, October, 1 (5): 4254 .

Gerçekçioğlu, R., Bilginer, S., Soylu, A., (2008). General Fruit Growing. Nobel Publishing, Ankara.

Gümüş, V. and Yenigün, K. (2006). Firat Havzas1 Akımlarının Trend Analizi İle Değerlendirilmesi, Harran Üniversitesi Fen Bilimleri Enstitüsü İnşaat Mühendisliği Anabilim Dalı Yüksek Lisans Tezi, Danışman: K. Yenigün, Şanlıurfa. (in turkish)

Karaçal, İ.(2004). Gübrelemede Çevreci Yaklaşımlar. Türkiye 3. Ulusal Gübre Kongresi, Tarım-Sanayi-Çevre, 11-13 Ekim, s: 647-654, Tokat. (in turkish)

Kendall, M.G. (1975). Rank Correlation Methods. Charles Griffin, p.135, London.

Mann, H.B. (1945). Non-parametric Tests Against Trend. Econometrica, 13: 245-259.

Sağlam, M.T. (2005). Fertilizer and Fertilization (7th Edition). T.U. Tekirdag Agricultural Faculty Publish, No. 149, Text Book No: 74, Tekirdag.

Submitted: 24.10.2015

Accepted: 11.12.2015 